\title{
Universuum of Institutional Development for Post Production Offshore Platform Decommissioning in Indonesia
}

\author{
Sari Amelia ${ }^{1 *}$, Ayomi D. Rarasati ${ }^{2}$, \\ A. Jaka Santos ${ }^{3}$ \\ ${ }^{1}$ Universitas Indonesia, Depok 16424, Indonesia \\ ${ }^{2,3,}$ Universitas Djuanda, Bogor 16720, Indonesia
}

\section{A B S T R A C T}

The objectives of the study are to review current institutional condition for post-production offshore platform decommissioning in Indonesia and to provide an institutional development analysis by applying universuum of institutional development model. This study is one of qualitative research that synthesized data from documentation through literature study. The output of the study is a comparison matrix between universuum of institutional development model and institutional development of post-production offshore platform decommissioning in Indonesia.

\section{ART I CLE I N F O}

Article History:

Received : 28.08,2019

Revised : :09.02.2020

Accepted : 20.02.2020

Published : 02-03-2020

Keywords:

Decommissioning

Institutional Development, Offshore Platform.

${ }^{*}$ Corresponding Author E-mail: asariamelia@hotmail.com

\section{INTRODUCTION}

Israel (1990) defined institutional development as a process to improve institution capacity to make human resource effective with the availability of financial. Idris (2012) mentioned that institutional development is an effort to improve the efficiency, effectiveness, and responsibility of institutional performance whether as government or private as well as the society in development implementation. Through in-depth interview, Amelia et al. (2018) found that one of success factor in offshore platform decommissioning is safety and efficiency on cost which can be achieved through project planning and management, used technology, as well as good coordination among the stakeholders. Meanwhile, Schroeder \& Love (2004) stated that the decision in offshore platform decommissioning relies on the authorized institution in policy formulation and public. In other words, there is an institutional issue that affect the success of 
the activity. Refer to Desrina et al. (2013), there are 4 (four) institutions involved in offshore platform decommissioning in Indonesia, i. e.: Ministry of Environment and Forestry, Ministry of Energy \& Mineral Resource, Ministry of Connectivity (c.q. General Directorate of Sea Transportation), and Ministry of Marine \& Fishery. In a case that post production offshore is re-use for artificial reef, it is also required the involvement of provincial government.

Earlier study in measuring policy implementation performance of offshore platform decommissioning Indonesia showed that the respective policy implementation is unsuccessful. Up to this date no record is found for postproduction offshore platform decommissioning. The constraint in fulfilling the policy objective lies in the capacity of the institution/actor in implementing the policy, especially in state asset management area. Wahab (2005) defined capacity of implementation as the ability of the institution/actor to conduct the policy implementation with objective to achieve the policy goal.

This study performs identification of variables for institution development of post-production offshore platform decommissioning in Indonesia by using Universuum of Institutional Development Model. This model is originally developed by Milton J. Esman (1971) and modified by Haryati (1994) base on institutional development definition of Joseph W. Eaton (1972).

Wibowo (1994) mentioned that the basic idea of institutional development perspective is how to create or to enlighten an institution, normally a formal institution, that encourage and unleash the execution of innovation process. Haryati (1994) defined this innovation as a norm and change value that is intended to be institutionalized. These norm and value may not exist previously. This perspective reflects the post production of offshore platform decommissioning case. As known, the oil and gas offshore activity had been started since 1971 by Atlantic Richfield Indonesia, Inc. in Arjuna Field, Northern of West Java Water.
The decommissioning issue is not critical earlier, but getting more attention recently. Due to one of oil and gas operator which is known as KKKS contract ended in December 2017, the KKKS provided offshore platform decommissioning initiative as per regulation to authorized institution for about 3 (three) years prior the end of concession period. In 2016/2017, the process is hold by respective authority with reason it is postponed until proper policy in state asset management is formulated, especially for platform write-off. This paper is a complementary of earlier study in policy analysis of post-production offshore platform decommissioning in Indonesia. The result of previous study in development of logical framework for measuring policy implementation performance of post-production offshore platform decommissioning in Indonesia is described as Figure 1.

\section{LITERATURE REVIEW}

Universuum of Institutional Development is originally developed by Milton J. Esman (1971) and by adopting institutional development definition of Joseph W. Eaton (1972), Haryati (1994) organized the model with objective to assess the institutional capacity. The model is described in Figure 2.

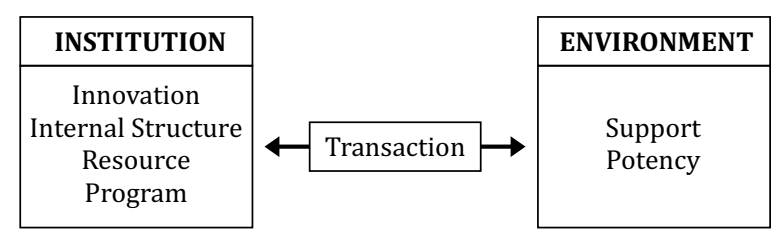

Figure 2. Universuum of Institutional Development (Haryati, 1994)

The model is explained by Haryati (1994) and Triana (2006) as follows:

1. Innovation, such norms and value changes that will be institutionalized in where those respective norms and value are not exist previously.

2. Internal structure, structure and process that support the institutionalization of program execution.

3. Resources, such as: human resources, fund sources, and required tools to support the institutionalization of program execution. 




Figure 1. Logical Framework for Measuring Policy Implementation Performance of Post Production Offshore Platform Decommissioning in Indonesia (Amelia et al, 2019)

4. Program, planned action to actualize the innovation.

5. Transaction, is defined as process to know, to develop, and to foster the network with environmental variables which is related to institutional activities.

\section{RESEARCH METHOD}

The study applies qualitative approach and most of collected data are categorized as secondary which are synthesized through documentation in literature study. Universuum of Institutional Development Model was adopted by Haryati (1994) to study the institutional development of independent family planning program (Keluarga Berencana Mandiri) in Ponorogo Regency, East Java. In earlier study, retrospective analysis was adopted to synthesize the required informations. Furthermore, the informations is also extracted and arranged in a form of Comparison Matrix for Universuum of Institution Development Model and Institutional Development of Post Production Offshore Platform Decommissioning as suggested by Haryati (1994). The research design is illustrated in Figure 3.

\section{RESULT AND DISCUSSION}

Table 1 shows all finding from policy analysis in literature study are arranged in a form of comparison matrix for Universuum of Institutional Development Model and Institutional Development of Post Production Offshore Platform Decommissioning.

As shown in Table 1, Institutional Variables in Universuum of Institutional Development is defined as Internal Factors, whilst Environmental Variables as External Factors. The comparison is described below.



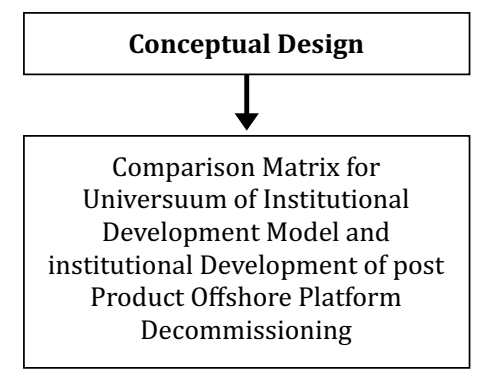

Figure 3. Research Design 
Table 1. Comparison Matrix for Universuum of Institutional Development Model and Institutional Development of Post-Production Offshore Platform Decommissioning

\begin{tabular}{|c|c|c|c|c|c|}
\hline \multicolumn{3}{|c|}{ DEVELOPMENT } & \multicolumn{3}{|r|}{ DECOMMISSIONING } \\
\hline \multirow[t]{11}{*}{ I } & \multicolumn{2}{|c|}{ Institutional Variables } & \multirow[t]{3}{*}{ I } & \multicolumn{2}{|c|}{ Internal Factors } \\
\hline & \multirow[t]{2}{*}{ I.1 } & \multirow[t]{2}{*}{ Innovation } & & \multirow[t]{2}{*}{ I.1 } & Effectiveness of processing time and to follow up of KKKS state asset write off proposal \\
\hline & & & & & Utilization of post production offshore platform through grant mechanism \\
\hline & \multirow[t]{2}{*}{ I.2 } & \multirow[t]{2}{*}{ Internal structure } & & \multirow[t]{2}{*}{ I.2 } & Evaluation team for post production offshore platform decommissioning \\
\hline & & & & & Internal team for preparation of grant proposal approval \\
\hline & \multirow[t]{3}{*}{ I.3 } & \multirow[t]{3}{*}{ Resources } & & \multirow[t]{3}{*}{ I.3 } & Human resources \\
\hline & & & & & Fund \\
\hline & & & & & Tools \\
\hline & \multirow[t]{3}{*}{ I.4 } & \multirow[t]{3}{*}{ Program } & & \multirow[t]{3}{*}{ I.4 } & Utilization for artificial reef \\
\hline & & & & & Utilization for fishing farm \\
\hline & & & & & Utilization for other purpose \\
\hline \multirow[t]{8}{*}{ II } & \multicolumn{2}{|c|}{ Enviromental Variables } & \multirow[t]{5}{*}{ II } & \multicolumn{2}{|c|}{ External Factors } \\
\hline & \multirow[t]{4}{*}{ II.1 } & \multirow[t]{4}{*}{ Support } & & \multirow[t]{4}{*}{ II.1 } & Enviromental resources \\
\hline & & & & & (a) Human resources \\
\hline & & & & & (b) Fund \\
\hline & & & & & (c) Tools \\
\hline & \multirow[t]{3}{*}{ II. 2} & \multirow[t]{3}{*}{ Potency } & & \multirow[t]{3}{*}{ II.2 } & Improvement of coastal water productivity \\
\hline & & & & & $\begin{array}{l}\text { Improvement of authorized financial audit agency (BPK) to government financial } \\
\text { report (LKPP) }\end{array}$ \\
\hline & & & & & Safety of navigation \\
\hline
\end{tabular}

I. Institutional Variables

a. Innovation

Refer to Bush (1988) in Haryati (1994), an innovation at least has a higher effectiveness value. Apriyadi (2009) found in his research that one of constrain in write-off process initiative for KKKS asset is long duration to process and to follow up the initiative that cause KKKS has no interest to take action.

b. Internal structure

As stated in Ministry Energy and Mineral Resource Regulation No. 15/2018 Article 6 Line (2) about Post Production Activity, General Director established Evaluation Team for Post Production Activity which is consisted of: General Directorate, Oil and Gas Task Force (SKK Migas), and/or respective institutions. The intended General Director is General Director who has task to formulate and implement the policy in coaching, controlling, and monitoring the oil and gas activity, i.e.: Oil and Gas General Director. Beside, Section $\mathrm{V}$ in Ministry of Finance Regulation
No. 111/2016 mentioned that, in grant mechanism, Goods User is required to establish an Internal Team to prepare the grant approval proposal to Goods Administrator. From these, it can be concluded that there are 2 (two) internal structures defined for decommissioning of oil and gas offshore platform in Indonesia, i.e.: evaluation team for offshore platform decommissioning and internal team for grant approval proposal.

c. Resources

Evaluation Team

Evaluation team for offshore platform decommissioning worked for 12 (twelve) months, with 3 (three) main duties below: (I) To evaluate post-production activity proposal which is submitted by KKKS to Directorate General of Oil and Gas.

(ii) To actualize periodic meeting or as necessary with objective to discuss evaluation result from team member as per each expertise to accelerate the evaluation process in post-production 
activity implementation.

(iii) To inform written report of evaluation result that had been discussed by the team to Directorate General of Oil and Gas for further approval.

\section{- Internal Team}

Detail info of internal team for grant proposal approval is mentioned in Article 93 and 95 of Ministry of Finance Regulation (PMK) No. 111/2016 about State Asset Transfer Procedure. Two main duties of the team are:

(i) To study the required administrative data which is further written in research report.

(ii) To conduct physical study for checking consistency of land and / or building with administrative data.

- Postproduction fund Utilization of post-production offshore platform decommissioning for other purposes in non oil and gas is financed by post production fund. SKK Migas Guideline (PTK) No. 40/2018 about Abandonment and Site Restoration (ASR) stated that KKKS transfers the fund in each semester in USD currency to escrow account as per agreed duration. Table 1 shows estimated cost required for in-situ and ex-situ rig-to-reef.

d. Program

Refer to SKK Migas Guideline (PTK) No. 40 about Abandonment and Site Restoration (ASR), utilization options for postproduction oil and gas offshore platforms for non-upstream oil and gas activities are rig to reef and fish farm. Though, it is also possible to be utilized for other option such: tourism, fish storage, renewable energy, research station, and military purpose. Of these, feasibility study of Research and Human Resource Institution for Marine and Fishery (BRSDMKP) showed that utilization for rig to reef as the most feasible alternative (Nugraha, 2019).

\section{Environmental Variables}

a. Support

In institutional system, support is defined as capacity to support an activity with objective to achieve the goal setting. Hence, the support from external factor in institutional development is the capacity of the environment to support institutional activity to actualize the innovation. Refer to Haryati (1994), those supports are: human resources, fund, and tools.

- Participation of local government

Desrina et al. (2013) described that participation of local government in policy formulation of oil and gas post production offshore platform utilization is one of necessary support in rig to reef. Example, for any offshore platform around Java Sea is possible to be re-use as artificial reef with the involvement of Jakarta and West Java Government. Whilst, feasibility study of rig to reef program for post-production offshore platform in ATTAKA Block involved Bontang Local Government as the Region Administrator (Nugraha, 2019).

- Artificial reef management fund in Conservation Water Region

Refer to Government Regulation No. 60/2007 about Fishery Resources Conservation. The financing sources for Conservation Water Region are state and/ or local budget, fishery fee, conservation service fee, and also other unbound approved sources.

\section{b. Potency}

In short, potency is potential capacity to be developed. Refer to the output and outcome of logical framework in offshore platform

Table 2. Estimated Cost for In-Situ and Ex-Situ Rig-to-Ref (ESD, 2017)

\begin{tabular}{|c|l|c|}
\hline No & \multicolumn{1}{|c|}{ Description } & Estimated Cost \\
\hline 1 & $\begin{array}{l}\text { In-situ rig-to-reef. Re-utilization of jacket as artificial reef in place after removing of well } \\
\text { conductor, production facility, and topside. }\end{array}$ & USD 31 Million \\
\hline 2 & $\begin{array}{l}\text { Ex-situ rig-to-reef. Re-utilization of jacket as artificial reef in designated location by Ministry } \\
\text { of Marine and Fishery after removing of well conductor, production facility, and topside. }\end{array}$ & USD 34 Million \\
\hline
\end{tabular}


decommissioning policy implementation performance, there are 3 (three) identified potencies of the environment.

- Improvement of coastal water productivity Feasibility study of Research and Human Resources Agency for Marine and Fishery (BRSDMKP) with Korean Maritime and Ocean University Consortium (KMOUC) found that artificial reef is one of the most effective approach to improve coastal water productivity by providing additional habitat for marine life (Nugraha, 2019).

- Improvement of authorized financial audit agency (BPK) opinion to government financial report (LKPP)

Margiadi (2017) stated that asset of KKKS potentially improve the opinion authorized financial audit agency (BPK) to government financial report (LKPP).

- Safety of navigation

Refer to Veronica (2009), neglected postproduction installation in the water may restrict the navigation route and endanger international lane. In other words, decommissioning and utilization of post- production offshore platform for other purpose eliminates any navigation danger/obstruction. Hence, potentially prevent any shipping accident especially collision between ship and platform.

\section{CONCLUSION}

By applying universuum of institutional development model, institutional development of post-production offshore platform decommissioning is defined in 2 (two) factors, i.e. internal and external. The internal factor refer to the institution itself, such as innovation, internal structure, resources, and program. Whilst, external factor is how the environment affect the institution through support and potency. By generating a comparison matrix between universuum of institutional development and institutional development of post-production offshore platform decommissioning in Indonesia, it can be concluded the innovation that should be developed are: (i) effectiveness of processing time and to follow up of state asset write off proposal, (ii) utilization of post-production offshore platform decommissioning.

\section{REFERENCES}

Amelia, S. et al. (2018). Perspective of Stakeholders for offshore platform decommissioning in Indonesia. Jurnal Ikatan Ahli Fasilitas Produksi Minyak dan Gas Bumi Indonesia (IAFMI).

Apriyadi, C. Y. (2009). Analisis desain alur proses dalam rangka penghapusan barang milik eks Kontraktor Kontrak Kerja Sama (KKKS) sub sektor migas. Jakarta: Universitas Indonesia.

Desrina, et al. (2013). Environmental impacts of the oil and gas platform decommissioning. Scientific Contributions Oil \& Gas.

Haryati, E. (1994). Pengembangan kelembagaan dalam program Keluarga Berencana Mandiri. Jakarta: Universitas Indonesia.

Israel, A. (1990). Pengembangan kelembagaan, pengalaman proyek-proyek Bank Dunia. Jakarta: LP3ES. Margiadi, B. (2017) Menata BMN yang berasal dari KKKS. Direktorat Jenderal Kekayaan Negara, Kementerian Keuangan.

Nugraha, R. B. A. et al. (2019). Rigs-to-reef (R2R); a new initiative on re-utilization of abandoned offshore oil and gas platforms in Indonesia for marine and fisheries sectors. IOP Conference Series: Earth and Environmental Science.

Schroeder, M. D. et al. (2004). Ecological and political issues surrounding decommissioning of oil facilities in the Southern California Bight. Ocean \& Coastal Management. 
Triana, R. W. (2006). Reformasi dan pembangunan lembaga: melembagakan tata kepemerintahan dan pelayanan publik. Jurnal Universitas Airlangga.

Veronica, E. (2009). Perspektif pengaturan terhadap instalasi tidak terpakai di landas kontinen Indonesia menurut hukum internal. Jakarta: Universitas Indonesia.

Wahab, S. A. (2005). Analisis kebijakan dari formulasi ke implementasi kebijakan negara. Jakarta: Bumi Aksara.

Wibowo, A. P. P. (1994). Pengembangan kelembagaan pengelolaan hutan tropis di Indonesia. Jakarta: Universitas Indonesia. 